\title{
The impact of coronary artery disease severity on late survival after combined aortic valve replacement and coronary artery bypass grafting - experience of a single cardiac surgery center
}

\author{
Bartłomiej Perek, Marcin Misterski, Wojciech Stachowiak, Piotr Buczkowski, Sebastian Stefaniak, \\ Mateusz Puślecki, Tomasz Urbanowicz, Wiktor Budniak, Marek Jemielity \\ Department of Cardiac Surgery and Transplantology, Poznan University of Medical Sciences, Poznan, Poland
}

Kardiochirurgia i Torakochirurgia Polska 2014; 11 (4): 361-366

\begin{abstract}
Introduction: The severity of coronary artery disease (CAD) may have an impact on the outcomes of patients (pts) after aortic valve replacement (AVR) and coronary artery bypass grafting (CABG).

Aim: The aim of the study was to analyze survival after simultaneous AVR and CABG with respect to CAD severity.

Material and methods: The study involved 143 consecutive pts (40 women and 103 men) with a mean age of $65.1 \pm 7.7$ years treated between 2006 and 2009. The indication for surgery was aortic stenosis accompanied by left main or threevessel disease (group $A ; n=43$ ) and by single- or two-vessel disease (group $B ; n=100$ ). In-hospital and late mortality were analyzed. Post-discharge survival was estimated using the Kaplan-Meier method. Moreover, selected preoperative clinical and echocardiographic data as well as intraoperative variables were compared between the groups.

Results: In-hospital mortality was $4.7 \%$ in group A and $3.0 \%$ in group B (NS). The 12-month and 48-month survival probability rates were $0.88 \pm 0.05$ and $0.83 \pm 0.06$ in group $A$, and $0.97 \pm$ 0.01 and $0.92 \pm 0.03$ in group $B$, respectively $(p<0.05)$. Patients in group $A$ and $B$ differed $(p<0.05)$ with respect to the preoperative prevalence of arterial hypertension ( $65.1 \%$ vs. $42.0 \%)$ and atrial fibrillation ( $18.6 \%$ vs. $6.0 \%$ ) as well as with regard to the rate of complete revascularization (20.9\% vs. $85.0 \%$, group $A$ and $B$, respectively).

Conclusions: Coronary artery disease severity impacts longterm survival after combined AVR and CABG. Patients with left main or three-vessel disease more often undergo incomplete surgical revascularization, and this fact may be one of the predictors of an unfavorable outcome.

Key words: coronary artery disease, aortic valve replacement, combined procedures, mortality, long-term outcomes.
\end{abstract}

\section{Streszczenie}

Wstęp: Zaawansowanie choroby wieńcowej może mieć wpływ na wyniki kliniczne leczenia chorych poddanych jednoczesnej wymianie zastawki aortalnej (aortic valve replacement - AVR) oraz pomostowaniu aortalno-wieńcowemu (coronary artery bypass grafting - $\mathrm{CABG}$ ).

Cel: Analiza przeżycia chorych po jednoczesnych zabiegach AVR i CABG zależnie od zaawansowania choroby wieńcowej.

Materiat i metody: Badaniem objęto 143 kolejnych chorych (40 kobiet i 103 mężczyzn) w wieku 65,1 \pm 7,7 roku leczonych w latach 2006-2009. Wskazaniem do operacji było zwężenie zastawki aortalnej ze wspótistniejącym zwężeniem pnia i chorobą trzech tętnic wieńcowych (grupa $A ; n=43$ ) lub chorobą jednej i dwóch tętnic wieńcowych (grupa $B ; n=100$ ). Analizowano zgony szpitalne i w obserwacji odległej. Przeżycie po wypisaniu ze szpitala oszacowywano z użyciem metody Kaplana-Meiera. Ponadto porównywano między grupami wybrane dane przed(kliniczne i echokardiograficzne) oraz śródoperacyjne.

Wyniki: Śmiertelność szpitalna wyniosła $4,7 \%$ w grupie $A$ oraz 3,0\% w grupie B (NS). Prawdopodobieństwo przeżycia 12 i 48 miesięcy oszacowano odpowiednio na 0,88 $\pm 0,05$ i 0,83 $\pm 0,06$ w grupie $A$ oraz $0,97 \pm 0,01$ i 0,92 $\pm 0,03 w$ grupie $\mathrm{B}(p<0,05)$. Chorzy $\mathrm{w}$ grupie $\mathrm{A}$ i $\mathrm{B}$ różnili się między sobą $(p<0,05)$ pod względem częstości występowania nadciśnienia tętniczego $(65,1 \%$ vs $42,0 \%)$ i migotania przedsionków $(18,6 \%$ vs $6,0 \%)$ oraz wykonania pełnej rewaskularyzacji serca $(20,9 \%$ vs $85,0 \%$, odpowiednio w grupie A i B; $p<0,001$ ).

Wnioski: Zaawansowanie choroby wieńcowej ma wpływ na przeżycie $w$ obserwacji odległej $u$ chorych poddanych jednoczesnym zabiegom AVR i CABG. U pacjentów z chorobą pnia i trzech tętnic wieńcowych częściej wykonuje się niepełną rewaskularyzację serca i ten fakt może być jednym z niekorzystnych czynników rokowniczych wyników odległych.

Stowa kluczowe: choroba wieńcowa, wymiana zastawki aortalnej, zabiegi łączone, śmiertelność, wyniki odległe. 


\section{Introduction}

Aortic stenosis (AS) and coronary artery disease (CAD) share risk factors (e.g., hypertension, hyperlipidemia, diabetes) and proposed pathophysiological mechanisms [1]. Individuals undergoing simultaneous operations for AS and CAD constitute a systematically growing group of patients; in some countries, their number has as much as doubled in recent years. It is generally accepted that the outcomes after combined procedures of aortic valve replacement (AVR) and coronary artery bypass grafting (CABG) are markedly worse than those after isolated AVR or isolated CABG [2, 3]. However, patients with AS and CAD usually have more independent risk factors for an unfavorable outcome, including age, impaired cardiac performance, or other comorbidities $[4,5]$. Moreover, co-existing CAD may vary with respect to the number of involved vessels, location (proximal, medial, or distal segments), and lesion severity (i.e., degree of stenosis). It has been suggested that CAD severity (defined as the number of diseased vessels) has an impact on the late outcomes of simultaneous AVR and CABG procedures $[6,7]$.

Thus, the purpose of this study was to analyze patient survival after combined procedures of AVR and CABG with respect to $C A D$ severity and to try to identify the possible reasons for the influence of CAD severity on late outcomes based on the experience of a single cardiac surgery center.

\section{Material and methods \\ Patients}

All consecutive patients who underwent simultaneous procedures of AVR for AS and CABG between January 2006 and December 2009 were enrolled in the study. Ultimately, the study encompassed 143 patients (40 females and 103 males) with a mean age of $65.1 \pm 7.7$ years (ranging from 43 to 79). The indication for surgery was AS accompanied by left main or three-vessel disease (group $A ; n=43$ ) and by one- or two-vessel disease (group B; $n=100$ ). Selected preoperative data of the patients enrolled in this study are outlined in Table I.

\section{Surgery}

Patients were qualified for surgery on the basis of echocardiographic study ( $M+2 D+$ Doppler) and coronary angiography. The findings of the preoperative examinations performed in both patient groups are summarized in Table II.

All operations employed median sternotomy, extracorporeal circulation (ECC) with moderate hypothermia $\left(28-29^{\circ} \mathrm{C}\right)$, and standard cannulation of the ascending aorta and right atrium. In all cases, cold cardioplegic solution according to the St Thomas Hospital formula was infused directly into the coronary ostia with an initial dose of $10 \mathrm{ml} / \mathrm{kg}$, repeated every 20 minutes. Retrograde infusion of the cardioplegic solution was applied only in a few cases with critical left main stenosis and complete occlusion of the proximal segment of the right coronary artery. During the surgery, the performance of distal anastomoses of the saphenous veins and radial arteries was followed by aortic valve replacement and the subsequent implantation of the left internal thoracic artery (LITA) (usually to the left anterior descending artery - LAD). After the aortic clamp had been released, the proximal anastomoses on the partially side-clamped ascending aorta were performed.

The most crucial details regarding the operations are listed in Table III. A modified definition of complete revascularization by Synnergren et al. was applied in our study. In short, surgical revascularization was considered complete when all arterial territories (LAD, circumflex artery [Cx], and right coronary artery [RCA]) with significantly stenotic segments (i.e., more than $70 \%$ on preoperative angiography) were bypassed by at least 1 bypass graft. In the case of left main disease (stenosis of at least $50 \%$ ), grafts had to be performed to both the LAD and Cx territories [8]. Completeness of revascularization was assessed retrospectively.

\section{In-hospital mortality and long-term survival}

In-hospital mortality, defined as death occurring within the first 30 postoperative days, was assessed irrespectively

Tab. I. Preoperative clinical data

\begin{tabular}{|c|c|c|c|}
\hline Variable* & Group A $(n=43)$ & Group B $(n=100)$ & $p$ \\
\hline Age (years) & $66.3 \pm 8.0$ & $64.5 \pm 7.5$ & 0.211 [NS] \\
\hline Gender (M/F) & $35(81.4 \%) / 8(18.6 \%)$ & $68(68.0 \%) / 32(32.0 \%)$ & 0.115 [NS] \\
\hline BMI & $30.6 \pm 4.8$ & $29.5 \pm 3.9$ & 0.330 [NS] \\
\hline Obesity (BMI > 30) & $20(46.5 \%)$ & $44(44.0 \%)$ & 0.925 [NS] \\
\hline Arterial hypertension & $28(65.1 \%)$ & $42(42.0 \%)$ & 0.019 \\
\hline Hyperlipidemia & $29(67.4 \%)$ & $58(58.0 \%)$ & 0.382 [NS] \\
\hline Diabetes & $15(34.9 \%)$ & $32(32.0 \%)$ & 0.877 [NS] \\
\hline Diabetes on insulin & $8(18.6 \%)$ & $20(20.0 \%)$ & 0.152 [NS] \\
\hline Previous MI & $13(30.2 \%)$ & 19 (19.0\%) & 0.208 [NS] \\
\hline $\mathrm{PCl}$ in history & $4(9.3 \%)$ & $4(4.0 \%)$ & 0.385 [NS] \\
\hline Atrial fibrillation ${ }^{\star *}$ & $8(18.6 \%)$ & $6(6.0 \%)$ & 0.023 \\
\hline
\end{tabular}

${ }^{*}$ Categorical variables are presented as numbers (\%) and continuous variables as mean \pm standard deviation.

${ }^{* *}$ At least one documented episode of atrial fibrillation.

$\mathrm{BMI}$ - body mass index, $\mathrm{F}$ - female, $\mathrm{M}$ - male, $\mathrm{MI}$ - myocardial infarction, $\mathrm{n}$ - number, $\mathrm{NS}$ - non-significant, $\mathrm{PCl}$ - percutaneous coronary intervention 
Tab. II. Preoperative echocardiographic and angiographic data

\begin{tabular}{|c|c|c|c|}
\hline Variable* & Group A $(n=43)$ & Group B $(n=100)$ & $p$ \\
\hline LVEDd (mm) & $49.0 \pm 8.5$ & $47.3 \pm 9.2$ & 0.699 [NS] \\
\hline LVPWd (mm) & $14.4 \pm 2.8$ & $15.2 \pm 3.2$ & 0.204 [NS] \\
\hline IVSd (mm) & $16.0 \pm 4.9$ & $16.1 \pm 3.0$ & $0.892[\mathrm{NS}]$ \\
\hline $\mathrm{LA}(\mathrm{mm})$ & $42.6 \pm 5.8$ & $40.3 \pm 7.0$ & $0.092[\mathrm{NS}]$ \\
\hline $\mathrm{RV}(\mathrm{mm})$ & $30.1 \pm 5.9$ & $28.6 \pm 4.8$ & $0.227[\mathrm{NS}]$ \\
\hline LVEF (\%) & $55.6 \pm 17.6$ & $58.8 \pm 15.9$ & $0.470[N S]$ \\
\hline LV dysfunction (LVEF $40 \%$ or less) ( $n$ [\%]) & $10(23.3 \%)$ & $15(15.0 \%)$ & $0.341[\mathrm{NS}]$ \\
\hline Regional abnormality in LV contractility ( $n[\%])$ & $18(41.8 \%)$ & $22(22.0 \%)$ & 0.026 \\
\hline Peak PG (mmHg) & $64.4 \pm 25.4$ & $89.2 \pm 27.9$ & $<0.001$ \\
\hline Peak PG $<60 \mathrm{mmHg}(n[\%])$ & $17(39.5 \%)$ & $18(18.0 \%)$ & 0.011 \\
\hline Peak PG $<60 \mathrm{mmHg}$ and LVEF $>40 \%(n[\%])$ & $15(34.9 \%)$ & $1(1.0 \%)$ & $<0.001$ \\
\hline Single-vessel disease ( $n[\%])$ & - & $65(65.0 \%)$ & N/A \\
\hline Two-vessel disease ( $n[\%])$ & - & $35(35.0 \%)$ & N/A \\
\hline Three-vessel disease ( $n[\%])$ & $23(53.5 \%)$ & - & N/A \\
\hline Isolated LM disease $(n[\%])$ & $8(18.6 \%)$ & - & N/A \\
\hline LM and RCA disease ( $n[\%])$ & $12(27.9 \%)$ & - & $\mathrm{N} / \mathrm{A}$ \\
\hline
\end{tabular}

${ }^{*}$ Categorical variables are presented as numbers (\%) and continuous variables as mean \pm standard deviation.

IVSd - interventricular septum diastolic thickness, LA - left atrial dimension, LM - left main, LV - left ventricular, LVEDd - left ventricular end-diastolic dimension, LVEF - left ventricular ejection fraction, LVPWd - left ventricular posterior wall diastolic thickness, RCA - right coronary artery, $n$ - number, N/A - non applicable, NS - non-significant, PG - pressure gradient, RV - right ventricular dimension

Tab. III. Intraoperative data

\begin{tabular}{|c|c|c|c|}
\hline Variable* & Group A $(n=43)$ & Group B $(n=100)$ & $p$ \\
\hline ECC time (min) & $119.0 \pm 23.9$ & $113.4 \pm 21.2$ & $0.339[N S]$ \\
\hline ACC time (min) & $89.7 \pm 18.5$ & $85.3 \pm 19.0$ & $0.352[\mathrm{NS}]$ \\
\hline$A V R+1$ graft & $7(18.6 \%)$ & 79 (79.0\%) & $<0.0001$ \\
\hline AVR +2 grafts & $26(60.6 \%)$ & $21(21.0 \%)$ & $<0.0001$ \\
\hline AVR +3 grafts & $9(20.9 \%)$ & - & N/A \\
\hline Bioprostheses/mechanical valves & $15(34.9 \%) / 28(65.1 \%)$ & $32(32.0 \%) / 68(68.0 \%)$ & $0.886[\mathrm{NS}]$ \\
\hline Complete revascularization ${ }^{* *}$ & $9(20.9 \%)$ & $85(85.0 \%)$ & $<0.0001$ \\
\hline \multicolumn{4}{|c|}{ Reasons for incomplete revascularization } \\
\hline Diffuse disease & 21 & 9 & $0.735[\mathrm{NS}]$ \\
\hline Small arteries & 12 & 5 & $0.832[\mathrm{NS}]$ \\
\hline Difficult access & 2 & 1 & $0.778[N S]$ \\
\hline
\end{tabular}

*Categorical variables are presented as numbers (\%) and continuous variables as mean \pm standard deviation.

${ }^{\star *}$ Complete revascularization is defined in the text (see subsection Surgery).

ACC - aortic cross clamping, AVR - aortic valve replacement, ECC - extracorporeal circulation, $n$ - number, N/A - non-applicable, NS - non-significant

of the actual location of the patients (our department, rehabilitation center, home).

The majority of our patients were referred to rehabilitation centers, routinely after 7-9 days after the operations. After the completion of postoperative rehabilitation, all patients were followed up at the outpatient clinic. If they were not supervised in the outpatient facilities, we tried to contact them or their families by phone at the end of the follow-up period. In the case of death, it was defined as cardiac- or non-cardiac-related.

\section{Data management and statistical analysis}

All continuous data were checked for normality with the Shapiro-Wilk $W$ test. If the values were normally distributed, they were expressed as mean \pm standard deviation and then compared (group A vs. group B) using Student's unpaired $t$-test. Nominal data were presented as numbers (n) and percentages (\%) and were compared with the Yeats corrected $\chi^{2}$ test. Differences with respect to ordinal variables (e.g., the number of diseased coronary arteries) were analyzed with the Kruskal-Wallis rank test. Post-discharge 
survival was estimated using the Kaplan-Meier method, and survival probability curves for both groups were compared with the Gehan-Wilcoxon test. A $p$ value $<0.05$ was considered statistically significant. All statistical analyses were performed using Statistica 9.0 for Windows (StatSoft, Inc., Tulsa, OK, USA).

\section{Results}

\section{Preoperative and intraoperative variables}

There were several differences between group $A$ and group $B$ with respect to both preoperative and intraoperative variables. More patients in group A had been diagnosed with arterial hypertension and had suffered at least one episode of atrial fibrillation according to their preoperative medical history (Table I). Echocardiographic parameters assessing cardiac dimensions and left ventricular systolic performance (i.e., left ventricular ejection fraction [LVEF]) did not differ between the subsets of patients (Table II). However, the degree of aortic stenosis, expressed as peak systolic transvalvular pressure gradient, was less severe in group A than in group B patients, even when patients with impaired LV systolic function (LVEF < 40\%) were taken into account. Fifteen cases in group $A$ and only 1 in group $B$ had a peak systolic transvalvular gradient below $60 \mathrm{mmHg}$ and relatively well-preserved LV performance (LVEF above 40\%) $(p<0.0001)$. Several significant differences were noted between the examined subgroups regarding the intraoperative variables; particularly, the rate of complete revascularization was significantly higher in group $B$ than in group $A$ $(p<0.0001)$ (Table III). The reasons for incomplete revascularization were, predominantly, diffuse CAD precluding appropriate anastomosis, narrow coronary arteries (less than $1 \mathrm{~mm}$ in diameter), and, rarely, coronary arteries inaccessible for grafting (intramuscular course, location in the atrioventricular groove).

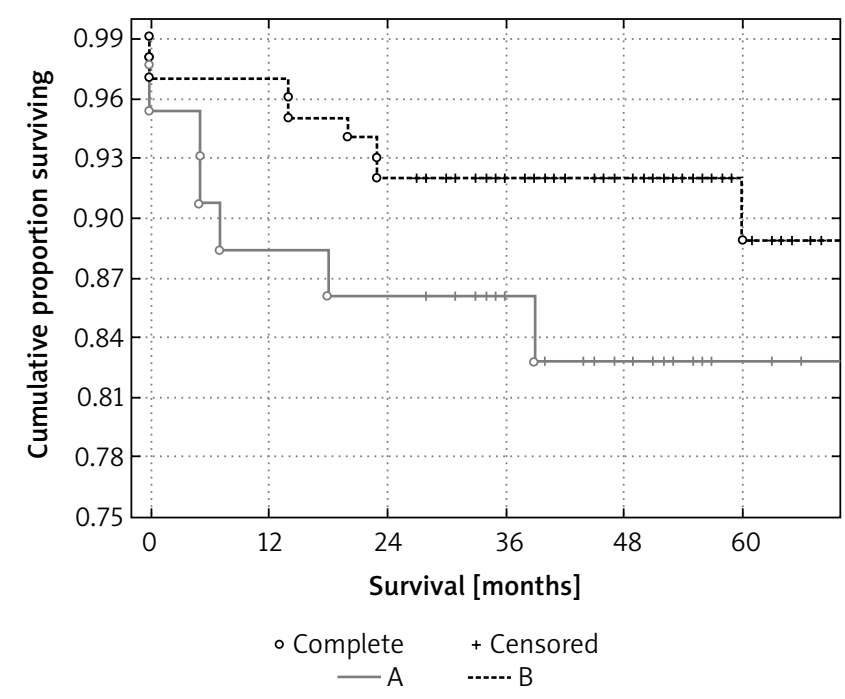

Fig. 1. Probability of patient survival assessed with the KaplanMeier curve. Statistical analysis (the Gehan-Wilcoxon test) revealed statistical significance $(p<0.05)$ with respect to long-term survival

\section{In-hospital period}

Five patients, including 2 in group $A$ (mortality rate $4.7 \%)$ and $3(3.0 \%)$ in group $B$, died during the early postoperative period (NS). Three of them died due to postoperative low cardiac output syndrome, and 2 died due to gastrointestinal complications.

Furthermore, the peak level of troponin I, detected usually 24 hours after the surgery, was significantly higher in group A than in group B $(18.9 \pm 7.6$ vs. $10.2 \pm 4.8 \mu \mathrm{g} /$; $p<0.001)$. Notwithstanding, pre-discharge transthoracic echocardiography $(M+2 D+$ Doppler) revealed additional postoperative disturbances in regional myocardial contractility (as compared to the preoperative assessment) in only 1 case in group A and 2 cases in group B (NS).

\section{Late outcomes}

During the post-discharge follow-up period, which lasted $45.5 \pm 17.5$ months (542.9 patient-years) and was completed by $98.6 \%$ of patients, 11 more individuals died ( 5 in group $A$ and 6 in group B). Cardiac-related deaths were noted in 4 cases in group A (80\%; due to myocardial infarction $[n=3]$ or progressive heart failure $[n=1]$ ) and 3 in group $B$ (50\%; heart failure $[n=2]$ or acute coronary syndrome $[n=1]$ ). Among them, only 1 group $B$ patient received complete surgical revascularization.

The probability of 12-month, 24-month, and 48-month survival calculated using the Kaplan-Meier curves was, respectively, $0.88 \pm 0.04,0.86 \pm 0.05$, and $0.83 \pm 0.06$ in group $A$ and $0.97 \pm 0.01,0.92 \pm 0.03$, and $0.92 \pm 0.03$ in group $B$ $(p<0.05)$ (Fig. 1).

\section{Discussion}

In our study, we have confirmed the earlier reports that the severity of CAD had an impact on patient survival after combined CABG and AVR procedures. Nonetheless, early mortality was similar in both study groups and was comparable to the findings of previously published studies $[9,10]$. The medical literature includes several reports confirming that the co-existence of both cardiac pathologies markedly increases early mortality in comparison to isolated AS or isolated CAD [11, 12]. Hemodynamically significant lesions in the coronary arteries may inhibit the effective perfusion of the usually hypertrophic myocardium with cardioplegic solution because of relatively high resistance to flow (high-resistance, low-flow perfusion areas) [13]. It is possible that the higher levels of troponin I in group $A$ resulted from insufficient intraoperative myocardial protection even though the retrograde perfusion technique was additionally applied in the particular cases (diagnosed with left main critical stenosis and occlusion of the proximal segments of the right coronary arteries). However, control echocardiography performed on the day prior to discharge did not reveal significant differences in regional myocardial contractility disturbances.

The present study demonstrated that the post-discharge follow-up period played the most important role 
in the difference in survival rates after combined AVR and CABG between the studied groups (A vs. B). Unfortunately, the relatively small number of patients enrolled in this study and the low mortality rate (only 16 subjects in both groups, including 8 group A patients) did not allow us to perform multivariate regression analysis in order to reveal the independent risk factors for the reduced survival rate in group A. Instead, we were only justified to compare selected perioperative variables between the studied groups of patients. Patients with more severe forms of CAD (group A) were more often diagnosed with arterial hypertension and were more likely to have suffered at least one episode of atrial fibrillation before surgery as compared to group B patients. These variables have been shown to have a significant adverse impact on the survival of patients undergoing AS surgery [14, 15]. Notwithstanding, the majority of our hypertensive patients had relatively well-controlled arterial blood pressure at the time of admission.

It is generally accepted that complete surgical revascularization should be a goal of CABG. However, there is no consensus on the clinical importance of complete revascularization in multivessel CAD. Some meta-analyses revealed that it might enable the achievement of better survival rates in comparison to incomplete revascularization, while the SYNTAX study did not support these findings $[8,16,17]$. This may be a result of some differences in the adopted definitions of complete revascularization. Some authors have taken into account all coronary arteries (Synnergren et al.), while others considered only those $>1 \mathrm{~mm}$ in diameter $[8,18]$. In our analysis, the more strict definition was adopted, and this fact may explain the low rate of complete revascularization in group $A$. There is a paucity of data on the effects of incomplete surgical revascularization on long-term outcomes after simultaneous AVR and CABG procedures. In our study, group A patients with pre-existing multivessel CAD presented a reduced survival rate in the late postoperative period. The majority of post-discharge deaths in group A were cardiac-related, particularly in con sequence of acute coronary syndromes. None of the group $A$ patients who died as a result of cardiac events during the follow-up had received complete surgical revascularization. It should be underscored once more that, in only one in every five group A patients, all the diseased coronary arteries were bypassed, predominantly due to diffuse atherosclerosis in the coronary arteries or the small diameters of the recipient vessels, especially in the Cx territory. Thus, the location of atherosclerotic plaques also appears to be of paramount importance for the late outcome. Isolated proximal lesions accompanied by peripheral segments of adequate diameter (i.e., > $1.5 \mathrm{~mm}$ ) in the recipient coronary vessels usually enable healthy anastomosis and favorable long-term follow-up. It is likely that the reduced long-term survival in group $A$ resulted from the more severe and more diffuse $C A D$, extending beyond the proximal segments of the coronary arteries, rather than from incomplete myocardial revascularization per se.

\section{Conclusions}

The study found that the severity of CAD has an impact on the long-term survival of patients undergoing combined AVR and CABG procedures. Patients with left main or three-vessel disease are more likely to undergo incomplete surgical revascularization, and this fact may be one of the predictors of an unfavorable outcome. However, incomplete revascularization is likely a result of more diffuse pre-existing CAD.

\section{Acknowledgements}

This study was presented at the $7^{\text {th }}$ Scientific Meeting of the Polish Society of Cardiothoracic Surgeons, Warsaw, June 5-7, 2014.

\section{Dislocure}

Authors report no conflict of interest.

\section{References}

1. Stefanini GG, Stortecky S, Meier B, Windecker S, Wenaweser P. Severe aortic stenosis and coronary artery disease. Eurolntervention 2013; 9 Suppl: S63-S68.

2. Alsoufi B, Karamlou T, Slater M, Shen I, Ungerleider R, Ravichandran P. Results of concomitant aortic valve replacement and coronary artery bypass grafting in the VA population. J Heart Valve Dis 2006; 15: 12-18.

3. Beach JM, Mihaljevic T, Svensson LG, Rajeswaran J, Marwick T, Griffin B, Johnston DR, Sabik JF 3rd, Blackstone EH. Coronary artery disease and outcomes of aortic valve replacement for severe aortic stenosis. J Am Coll Cardiol 2013; 61: 837-848.

4. Sareyyupoglu B, Sundt TM 3rd, Schaff HV, Enriquez-Sarano M, Greason KL, Suri RM, Burkhart HM, Park SJ, Dearani JA, Daly RC, Orszulak TA. Management of mild aortic stenosis at the time of coronary artery bypass surgery: should the valve be replaced? Ann Thorac Surg 2009; 88: 1224-1231.

5. Dagenais F, Mathieu P, Doyle D, Dumont É, Voisine P. Moderate aortic stenosis in coronary artery bypass grafting patients more than 70 years of age: to replace or not to replace? Ann Thorac Surg 2010; 90: 1495-1499.

6. Kobayashi KJ, Williams JA, Nwakanma L, Gott VL, Baumgartner WA, Conte JV. Aortic valve replacement and concomitant coronary artery bypass: assessing the impact of multiple grafts. Ann Thorac Surg 2007; 83: 969-978.

7. Li Z, Anderson I, Amsterdam EA, Young JN, Parker J, Armstrong EJ. Effect of coronary artery disease extent on contemporary outcomes of combined aortic valve replacement and coronary artery bypass graft surgery. Ann Thorac Surg 2013; 96: 2075-2082.

8. Synnergren MJ, Ekroth R, Odén A, Rexius H, Wiklind L. Incomplete revascularization reduces survival benefit of coronary artery bypass grafting: Role of off-pump surgery. J Thoracic Cardiovasc Surg 2008; 136: 29-36.

9. Saxena A, Shi WY, Paramanathan A, Herle P, Dinh D, Smith JA, Reid CM, Shardey G, Newcomb AE. A propensity-score matched analysis on the impact of postoperative atrial fibrillation on the early and late outcomes after concomitant aortic valve replacement and coronary artery bypass graft surgery. J Cardiovasc Med (Hagerstown) 2014; 15: 199-206.

10. Saxena A, Paramanathan A, Shi WY, Dinh DT, Reid CM, Smith JA, Shardey GC, Newcomb AE. Impact of left ventricular dysfunction on early and late outcomes in patients undergoing concomitant aortic valve replacement and coronary artery bypass graft surgery. Cardiol J 2013; 20: 423-430.

11. Jones JM, Lovell D, Cran GW, MacGowan SW. Impact of coronary artery by pass grafting on survival after aortic valve replacement. Interact Cardiovasc Thorac Surg 2006; 5: 327-330.

12. Chikwe J, Croft LB, Goldstone AB, Castillo JG, Rahmanian PB, Adams DH, Filsoufi $\mathrm{F}$. Comparison of the results of aortic valve replacement with or without concomitant coronary artery bypass grafting in patients with left ventricular ejection fraction $<$ or $=30 \%$ versus patients with ejection fraction >30\%. Am J Cardiol 2009; 104: 1717-1721.

13. Kouerinis IA, Manopoulos GC, Zografos G, Apostolakis El, Tsilimingas NB, Argiriou ME, Gorgoulis VG, Dedeilias PG, Tsoukas A, Bolos K, Tsangaris SG. 
Retrograde cardioplegia in CABG: is it really useful? The microcirculation and a capillary unit model. Med Sci Monit 2006; 12: 265-268.

14. Tjang YS, van Hees Y, Körfer R, Grobbee DE, van der Heijden GJ. Predictors of mortality after aortic valve replacement. Eur J Cardiothorac Surg 2007; 32: 469-474.

15. Saxena A, Dinh D, Dimitriou J, Reid C, Smith J, Shardey G, Newcomb A. Preoperative atrial fibrillation is an independent risk factor for mid-term mortality after concomitant aortic valve replacement and coronary artery bypass graft surgery. Interact Cardiovasc Thorac Surg 2013; 16: 488-494.

16. Takagi H, Watanabe T, Mizuno Y, Kawai N, Umemoto T; ALICE (All-Literature Investigation of Cardiovascular Evidence) Group. A meta-analysis of adjusted risk estimates for survival from observational studies of complete versus incomplete revascularization in patients with multivessel disease undergoing coronary artery bypass grafting. Interact Cardiovasc Thorac Surg 2014; 18: 679-682.

17. Head SJ, Mack MJ, Holmes DR Jr, Mohr FW, Morice MC, Serruys PW, Kappetein AP. Incidence, predictors and outcomes of incomplete revascularization after percutaneous coronary intervention and coronary artery bypass grafting: a subgroup analysis of 3-year SYNTAX data. Eur J Cardiothorac Surg 2012; 41: 535-541.

18. Kieser TM, Curran HJ, Rose S, Norris CM, Graham MM. Arterial grafts balance survival between incomplete revascularization: A series of 1000 consecutive coronary artery bypass graft patients with $98 \%$ arterial grafts. J Thorac Cardiovasc Surg 2014; 147: 75-84 